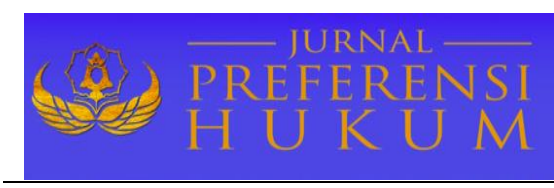

Jurnal Preferensi Hukum | ISSN: 2746-5039

Vol. 2, No. 1 -Februari 2021, Hal. 16-21| Available online at https://www.ejournal.warmadewa.ac.id/index.php/juprehum

DOI: https://doi.org/10.22225/jph.2.1.3044.16-21

\title{
PERKAWINAN BEDA AGAMA DALAM PERSPEKTIF HAK ASASI MANUSIA DI INDONESIA
}

Made Widya Sekarbuana, Ida Ayu Putu Widiawati, I Wayan Arthanaya

Fakultas Hukum Universitas Warmadewa Denpasar, Bali, Indonesia

\begin{abstract}
Abstrak
Kehadiran Undang-Undang Nomor 1 Tahun 1974 tentang perkawinan tidak dapat memberikan perlindungan hukum secara utuh dalam setiap fenomena perkawinan, khususnya dalam perkawinan beda agama di Indonesia. Suatu ikatan pernikahan disahkan berdasarkan hukum agama, namun Hak Asasi Manusia sebagai hak istimewa yang menegaskan kebebasan melangsungkan perkawinan dan memeluk agama sebagai hak dasar yang tidak dapat diintervensi oleh siapapun. Penelitian ini bertujuan untuk menjelaskan pengaturan perkaiwnan beda agama di Indonesia dan menjelaskan konsekuensi logis perkawinan beda agama ditinjau dari persepektif hak asasi manusia. Penelitian iini didesain menggunakan penelitian hukum normatif, dengan studi kepustakaan dari bahan hukum primer dan sekunder. Hasil penelitan menunjukkan bahwa undang-undang perkawinan belum memberikan kepastian bagi pasangan yang melangsungkan perkawinan beda agama, masih terdapat kekaburan norma mengenai perkawinan beda agama dan konflik norma mengenai sahnya perkawinan dengan kebebasan memeluk agama, selanjutnya Perkawinan beda agama dinilai diskriminatif, karena agama merupakan hak dasar yang telah dilindungi Undang-Undang dan tidak ada yang diperbolehkan mencampurinya, maka fenomena tersebut menimbulkan konsekuensi bagi salah satu pihak dengan menundukan diri mengikuti agama pasangannya. Dari hal tersebut pemerintah diharapkan melakukan pengamatan mengenai efektivitas aturan perkawinan diIndonesia serta melakukan harmonisasi agar tidak terjadi kosong, kabur atau konflik norma dalam hal perkawinan.
\end{abstract}

Kata Kunci: Perkawinan; Perkawinan Beda Agama; Hak Asasi Manusia

\begin{abstract}
The presence of Law Number 1 of 1974 concerning marriage cannot provide complete legal protection in every phenomenon of marriage, especially in interfaith marriages in Indonesia. A marriage bond is legalized based on religious law, but human rights as a privilege that affirms the freedom to have a marriage and embrace religion as basic rights that cannot be intervened by anyone. This study aims to explain the arrangements for interfaith marriage in Indonesia and to explain the logical consequences of interfaith marriage from a human rights perspective. This research is designed to use normative legal research, with literature study of primary and secondary legal materials. The results of the research show that the marriage law has not provided certainty for couples who have interfaith marriages, there are still obscure norms regarding interfaith marriages and conflict of norms regarding the validity of marriage and freedom to embrace religion, then interfaith marriage is considered discriminatory, because religion is a basic right which has been protected by law and no one is allowed to mix it, then this phenomenon has consequences for one of the parties by submitting to the religion of his partner. From this, the government is expected to make observations about the effectiveness of marriage regulations in Indonesia and carry out harmonization so that there are no empty, blurred or conflicting norms in matters of marriage.
\end{abstract}

Keywords: Marriage; Marriage with different religions; Human rights

\section{PENDAHULUAN}

Negara Indonesia merupakan negara hukum dengan sistem hukum bersifat majemuk, hal tersebut ditunjukan melalui corak khas yakni gabungan antara sistem hukum adat, sistem hukum agama, dan sistem hukum barat (Taufik, 2013). Adanya sifat tersebut otomatis akan berpengaruh terhadap hukum positif yang dianut, salah satunya adalah sistem hukum perkawinan yang berlaku sampai dengan saat ini. Manusia merupakan subyek hukum yang tergolong sebagai makhluk multidimensional, memiliki akal pikiran dan kemampuan berinteraksi secara personal maupun sosial. Hal tersebut yang membuat manusia selalu membutuhkan orang lain dalam proses kehidupannya untuk bersama-sama berkolaborasi menjalankan fungsi sosial.

Kelompok sosial terkecil dari masyarakat adalah individu dalam sebuah keluarga, semua berawal dari rumah dalam artian keluarga kecil, untuk itu manusia memiliki hak untuk menentukan kebahagiaan dan bebas menentukan pilihan termasuk dalam hal pasangan hidup yang kelak akan 
hidup bersama dalam sebuah keluarga. Lahirnya sebuah keluarga kecil diawali dengan adanya sebuah peristiwa hukum yang disebut sebagai perkawinan, maka ikatan perkawinan dinilai sebagai lembaga yang menentukan kedudukan seseorang dihadapan mata hukum, karena peristiwa yang tergolong ke dalam peristiwa hukum akan menimbulkan akibat hukum berupa hak dan kewajiban.

Undang-Undang Dasar Negara Republik Indonesia Tahun 1945 mengakui bahwa perkawinan merupakan perbuatan hukum yang dilindungi Undang-Undang sebagai hak asasi yang dimiliki oleh setiap warga negara, hal tersebut temuat tegas dalam Pasal 28B ayat(1). Aturan dasar tersebut diperkuat dengan keberadaan Undang-Undang Nomor 1 Tahun 1974 Tentang Perkawinan yang hadir sebagai jawaban dalam memenuhi kebutuhan terhadap kepastian hukum tentang perkawinan di Indonesia. Kehadiran Undang-Undang Perkawinan (UUP) ternyata tidak secara utuh menjelaskan berbagai fenomena perkawinan yang terjadi di Indonesia, seperti halnya perkawinan yang dilakukan oleh pasangan dengan agama yang berbeda. Hanya saja pada Pasal 2 ayat (1) UUP menyatakan sahnya perkawinan, apabila dilakukan menurut hukum masing-masing agama dan kepercayaannya itu. Fenomena inilah yang banyak timbul polemik serta pandangan pro dan kontra. Aspek lain yang tidak dapat dikesampingkan adanya hak asasi manusia yang telah diakui dunia, Indonesia sendiri memberikan payung hukum bagi hak istimewa tersebut melalui Undang-Undang 39 Tahun 1999 tentang Hak Asasi Manusia. Dalam aturan tersebut Pasal 22 menjelaskan bahwa setiap orang memeluk agamanya masing-masing dan untuk beribadat menurut agama dan kepercayaannya itu. Realisasi perkawinan beda agama menjadi sebuah kacamata paradok dalam usulan hak memeluk agama dalam perkawinan. Pada sisi yang berlainan, pasangan yang menganut agama berlainan akan bermasalah untuk menyatukannya menjadi perkawinan secara sah, sehingga salah satu pihak perlu penundukan diri kepada agama pasangannya (Yonesta et al., 2012). Pada sisi sebaliknya, negara telah menjamin kebebasan setiap warga negaranya untuk bebas menentukan pilihan termasuk dalam hal memeluk agama. Adanya penolakan terhadap perkawinan beda agama termasuk perilaku diskriminatif, karena telah keluar dari prinsip HAM itu sendiri.

Peneletian terdahulu mengungkapkan bahwa Hak asasi Manusia yang ada di Indonesia, bukanlah Hak Asasi Manusia yang sekuler, yang memisahkan agama dari Negara, yang melegalkan segala cara atas nama "HAM", ini jelas bertentangan dengan Pancasila sila pertama, dan ini tidak masuk dalam jati diri bangsa Indonesia (Daeng \& Ariga, 2017). Pernikahan beda agam pada dasarnya dilarang, akan tetapi terdapat pengecualian apabila pasangan laki-laki adalah seorang mukmin dan pasangan perempuan adalah ahli, pada pasangan semacam inilah para ulama' berbeda pendapat dalam menghukumi. Kaidah ushul fiqh “ idza ijtama'a baina al halal wal haram ghuliba al haram” bisa dijadikan solusi dalam pengambilan hukum sebagai bentuk ihtiyaat atau kehati-hatian dalam pelaksanaan syariah Islam (Dardiri \& Tweedo, 2013). Perjanjian perkawinan merupakan persetujuan perjanjian secara tertulis yang dibuat oleh pasangan calon suami istri dilakukan pada waktu atau sebelum pekawinan dilangsungkan yang disahkan oleh pegawai pencatat perkawinan, maka isi perjanjian perkawinan tersebut mengikat para kedua belah pihak (calon suami istri) dan juga pihak ketiga sepanjang pihak ketiga tersebut tersangkut (Kambey, 2017). Penelitian ini bertujuan untuk mengetahui pengaturan perkaiwnan beda agama di Indonesia dan menjelaskan konsekuensi logis perkawinan beda agama ditinjau dari perspektif hak asasi manusia.

\section{METODE PENELITIAN}

Tipe penelitian ini tergolong penelitian hukum normatif, yaitu penelitain terhadap asas-asas hukum, penelitian terhadap sistematika hukum dan penelitian terhadap sinkronisasi hukum, sumber data yang digunakan adalah bahan hukum primer meliputi Undang-Undang Dasar 1945, Undang-Undang Nomor 1 Tahun 1974 tentang Perkawinan, Undang-Undang Nomor 39 Tahun 1999 tentang Hak Asasi Manusia. Bahan Hukum Sekunder meliputi literatur, artikel, hasil-hasil penelitian. Pengumpulan bahan hukum dilakukan dengan cara memeriksa, mengumpulkan dan menelusuri dokumen kepustakaan dengan pencatatan yang kemudian dijadikan bahan sebagai analisis permasalahan agar dapat menarik simpulan sebagai bentuk interpretasi atas objek secara konsisten hingga memberikan saran sesuai permasalahan. Selanjutnya setelah data penelitian terkumpul dianalisis dengan menggunakan analisis deskriptif (Ahmad, 2008). 


\section{HASIL DAN PEMBAHASAN}

\section{Pengaturan Perkaiwnan Beda Agama di Indonesia}

Negara Indonesia sebagai negara yang memiliki keanekaragaman suku, budaya, ras, adat istiadat, bahasa dan agama. Keragaman tersebut, tidak mampu membatasi kodrat manusia sebagai makhluk sosial yang membutuhkan orang lain. Keinginan untuk hidup bersama direalisasikan dalam sebuah iktan perkawinn yang sah. Bagi setiap warga negara yang akan melangsungkan perkawinan, maka perlu mencermati makna atas perkawinan yang telah ditegaskan dalam Undang-Unang Nomor 1 Tahun 1974 tentang Perkawinn bahwa perkawinan ialah ikatan lahir batin antara seorang pria dengan seorang wanita sebagai suami istri dengan tujuan membentuk keluarga yang bahagia dan kekal berdasarkan Ketuhanan Yang Maha Esa. Definisi tersebut membangun makna mengenai ikatan lahir merupakan hubungan yang dibina antara kedua belah pihak dan hubungan dengan masyarakat yang berkaitan dengan tanggung jawab keluarga dihadapan masyarakat, sedangkan ikatan batin lebih menekankan rasa batiniah yang mengandung kemantapan dan niat atas kesungguhan untuk hidup bersama.

Undang-Undang Perkawinan menentukan sahnya perkawinan dalam Pasal 2 Ayat(1) bahwa perkawinan sah, apabila dilakukan menurut hukum masing-masing agama dan kepercayaannya itu. Sahnya perkawinan di Indonesia dinilai memiliki kekentalan nuansa agama, unsur agamawi yang mendominasi syarat sahnya perkawinan, maka terjadi degradasi capaian tujuan unifikasi UndangUndang Perkawinan yang mengacu pada keseragaman terselenggaranya perkawinan bagi setiap warga negara (J, 1995) Ketentuan pasal tersebut memiliki sifat dualistis, yang masih terasa kabur karena agama masih dijadikan tolak ukur penentu keabsahan perkawinan.

Sahnya perkawinan juga termuat dalam Pasal 2 ayat (2) bahwa tiap-Tiap perkawinan dicatat menurut peraturan perundang-undangan yang berlaku. Ketentuan tersebut memandang sahnya perkawinan secara hukum demi tertibnya administratif, karena hal ini akan berimplikasi terhadap ketentuan-ketentuan dalam peristiwa hukum yang lain. Pencatatan perkawinan juga didasarkan pada agama yang dimiliki, apabila beragama Islam maka perkawinan dicatatkan oleh pegawai pencatat nikah, talak dan rujuk, sedangkan selain agama Islam pencatatan dilakukan di kantor catatan sipil.

Perkawinan yang tidak dicatatkan di lembaga berwenang akan berakibat hukum bagi pasangan tersebut yang meliputi: a) status perkawinan yang telah dilangsungkan menurut agama dan kepercayaannya dianggap sah oleh agama namun tidak diakui oleh negara, maka tidak memiliki kepastian hukum karena tidak memiliki bukti otentik berupa akta perkawinan; b)status anak yang lahir tidak memiliki kejelasan status, bahkan dapat dikatakan sebagai anak luar kawin sebagaimana definisi anak dalam Pasal 42 dan Pasal 43 UUP; c) terhadap harta kekayaan juga akan menimbulkan kekaburan terhadap status harta bawaan dan harta bersama, maka akan sulit bagi kedua belah pihak untuk mengajukan pembagian harta bersama ke pengadilan.

Ketentuan khusus yang mengatur mengenai syarat perkawinan dibagi dalam dua hal yang meliputi syarat materiil dan syarat formil. Syarat materiil merupakan syarat yang melekat pada setiap peribadi para pihak, dimana materiil dibagi dalam materiil absolut yang menekankan pada syarat umum termuat dalam Pasal 6 dan Pasal 7 UUP, kemudian syarat materiil relatif menekankan ketentuan larangan kawin dengan orang tertentu termuat dalam Pasal 8 sampai dengan Pasal 11 UUP. Syarat formil menekankan pada prosedur perkawinan menurut agama dan undang-undang termuat dalam Pasal 12 UUP.

Secara yuridis Undang-Undang Perkawinan mengkonsepkan aturan perkawinan di Indonesia sebagai berikut: 1) Pasal 1ayat(1) memberikan definisi perkawinan yang menegaskan sebagai ikatan lahir batin sehingga memiliki hubungan yang intim terkait tujuan dari perkawinan yakni bahagia dan kekal. 2) Pasal 2 ayat (1) (2) menjelaskan sahnya perkawinan yang menegaskan bahwa agama menjadi patokan perkawinan dianggap sah, wlaupun setiap agama yang dipeluk memiliki aturan hukum yang berbeda-beda. Serta pencatatan menjadi syarat sah perkawinan atas hukum negara demi tertib administratif. 3) Pasal 3 ayat(1) (2) menjelaskan mengenai asas monogami dalam perkawinan di Indonesia, walaupun dpat dikesampingkan dengan alasan-alasan tertentu. 4) Pasal 7 menjelaskan mengenai batas usia para pihak, laki-laki berusia 19 tahun dan wanita berusia 16 tahun. Usia tersebut diharapkan bahwa para pihak telah siap jiwa dan raga untuk melangsungkan perkawinan dan berkaitan dengan perihal kependudukan. 5) Pasal 38 dijelaskan mengenai putusnya perkawinan yang diperkuat dalam Pasal 39 ayat (1) (2) (3) yang pada intinya memungkinkan perceraian memiliki alasan jelas untuk dijelaskan dalam sidang pengadilan. 
Perkawinan yang terjalin antara seorang laki-laki dan wanita berbeda agama bukan lagi menjadi hal tabu di masyarakat heterogen, walaupun selalu menimbulkan pandangan-pandangan berbeda dibidang sosial dan hukum. Sebelum berlaku Undang-Undang Nomor 1 Tahun 1974, Indonesia masih tunduk pada produk hukum Belanda yang disebut Regling op de Gemengde Huwelijken (GHR) atau disebut sebagai perkawinan campuran, namun definisi perkawinan campuran terebut adalah perkawinan antara orang Indonesia yang tunduk pada hukum berlainan. Indonesia tunduk pada ketentuan yang memecahkan persoalan dari perkawinan campuran yang dalam hal ini perkawinan beda agama yang seharusnya diluar dari perkawinan campur namum termasuk dalam ruang lingkup perkawinan campur (Gautama, 1980). Dengan begitu perkawinan yang dilaksanakan dalam beda agama telah memiliki perlindungan atas kepastian hukum, walaupun hukum agama memiliki persepsi berlainan. Setelah berlaku Undang-Undang Nomor 1 Tahun 1974 sebagai langkah era unifikasi hukum perkawinan yang memastikan tunduk pada satu hukum postif, realisasinya masih menunjukan dualisme yang dirumuskan pada Pasal 2 ayat(1) yang menitik beratkan pada eksistensi hukum agama. Pasal tersebut juga dianggap telah menutup pintu keberlangsungan perkawinan beda agama. Tafsir pada sisi lain menganggap perkawinan tersebut tidak memenuhi ketentuan berdasarkan undangundang, karena memeluk agama merupakan hak dasar sesuai Pasal 29 ayat (2) UUD 1945, namun ada yang berpendapat bahwa pasangan beda agama sah sepanjang dilakukan berdasarkan agama salah satu pihak. Untuk itu timbul alternatif dalam mencari sahnya perkawinan bagi pasangan beda agama dengan cara: memohon penetapan pengadilan, dilakukan menurut agama masing-masing, penundukan sementara pada salah satu hukum agama, dan perkawinan dilakukan di luar negeri. Perkawinan yang dilakukan diluar negeri telah memberikan peluang yang dapat digunakan sebagai sarana melegalkan perkawinan tersebut dalam Pasal 56 Undang-Undang Perkawinan.

\section{Konsekuensi Logis Perkawinan Beda Agama Ditinjau dari Persepektif Hak Asasi Manus}

Pada dasarnya tindakan penolakan terhadap perkawinan beda agama di Indonesia merupakan hal yang diskriminatif, karena tidak sesuai dengan prinsip dasar Hak Asasi Manusia yang membatasi agama warga negaranya. Agama dinilai sebagai poin penting bagi jiwa pada setiap insan, maka UUDNRI 1945 sebagai peraturan perundang-undangan tertinggi telah menjamin hal tersebut. Melalui Pasal 28 E ayat(1) dan Pasal 29 ayat(2) mengenai kebebasan memeluk agama, kebebasan dalam hal ini diartikan sebagai hal yang hakiki maka tidak ada turut campur negara sekalipun. Secara filosofis, pengaturan hak dasar bidang perkawinan belum diselaraskan denan peraturan perundang-undangan karena tidak sesuai dengan cita-cita penegakan HAM.

Hakekatnya Pasal 10 ayat(2) Undang-Undang HAM menyatakan bahwa perkawinan yang sah hanya dapat dilakukan atas kehendak bebas dari kedua pihak, pasal ini mengandung prinsip atas kehendak bebas dari pasangan dalam ikatan perkawinan. Makna dari kehendak bebas adalah kemauan yang lahir atas dasar niat suci yang tulus tanpa paksaan, penipuan dan tekanan. Undang-Undang HAM hanya melihat aspek keperdataan bahwa tidak ada unsur agama yang diutamakan dalam ikatan perkawinan yang sah. Undang-Undang Perkawinan sampai saat ini masih mengkonsepkan sahnya perkawinan atas dasar agama.

Hak untuk berkeluarga dan melanjutkan keturunan melalui ikatan perkawinan yang sah seharusnya dilakukan berdasarkan Pasal 10 ayat(2) dan Pasal 3 ayat(3) yang tidak boleh dikurangi atau reduksi dengan alasan agama. Pada realitanya, status keagamaan pada setiap pasangan beda agama dapat dilihat berdasarkan cara pasangan tersebut melangsungkan perkawinan. Endogami agama memang sebagai perkawinan ideal bagi semua agama, namun perkawinan beda agama memiliki dampak bagi salah satu pihak jika ditempuh dengansalah satu pihak bersedia menundukan diri yakni harus mengikuti agama pasangannya.

Secara yuridis, Undang-Undang Perkawinan tidak melarang adanya perkawinan yang dilakukan oleh pasangan dengan agama yang berbeda, Undang-Undang Perkawinan secara tidak langsung telah memberikan celah bagi perkawinan beda agama dengan memperhatikan penafsiran Pasal 56 UndangUndang Perkawinan. Secara sosiologis, bahwa manusia merupakan makhluk sosial yang akan senantiasa berkembang dan berkumpul dengan sesamanya tanpa memandang latar belakang pasangan tersebut sekalipun dalam hal agama. Secara filosofis, mengenai hak yang berkaitan dengan agama. Hak memeluk agama merupakan hak dasar yang tidak dapat dibagi atau dikurangi bahkan didiskriminasikan, apabila hal tersebut terjadi maka telah terjadi pelanggaran terhadap UndangUndang Dasar dan asas dasar dari Hak Asasi Manusia itu sendiri. Penafsiran mengenai perkawinan 
beda agama yang dilarang, dari sudut pandang Hak Asasi Manusia telah melakukan pelanggaran atas hak dasar tersebut yakni memeluk agama dan keyakinannya masing-masing (Usman, 1989).

Negara dituntut untuk benar-benar menjamin hak dasar masyarakatnya. Perkawinan yang sah merupakan bagian hak yang dimiliki warganegara, walaupun pasangan tersebut memiliki agama secara berlainan. Negara perlu hadir untuk memberikan kejelasan aturan secara konkrit demi terealisasinya bentuk harmonisasi ketentuan yang berlaku dan fakta di masyarakat. Pemberlakuan akibat hukum hanya didasarkan pada perbuatan hukum saja yakni kualifikasi oleh hukum sebagai perbuatan hukum dan tidak termasuk perbuatan sosial. Terdapat tiga macam akibat hukum dari sebuah ikatan perkawinan yakni: adanya hubungan suami istri, adanya hubungan orangtua dengan anak, serta masalah harta kekayaan (HS, 2014).

Hubungan hukum antara suami dan istiri sejak ikatan perkawinan dinyatakan sah, maka secara otomatis akan timbul hubungan hukum sebagai suami dan isteri. Hubungan hukum tersebut akan menimbulkan hak dan kewajiban. Undang-Undang Perkawinan telah mengatur hak dan kewajiban suami isteri dalam Pasal 30 sampai dengan Pasal 34. Pasal tersebut telah menguraikan secara pasti sesuatu yang telah menjadi hak serta kewajiban suami isteri. Adanya perbedaan agama dalam ikatan perkawinan tidak menyebabkan salah satu pihak memiliki keistimewaan hak dan kewajiban satu dengan yang lain.

Hak dan kewajiban antara suami dan isteri memiliki sistematika yang menunjukan bahwa posisi anatar keduanya menurut hukum berlaku seimbang, tidak ada yang lebih kuat ataupun yang lebih lemah. Sesuai dengan Pasal 34 ayat(3) apabila terdapat salah satu pihak yang merasa dirugikan atau terjadi pelanggaran atas haknya, pihak yang merasa rugi dapat mengajukan gugatan kepada Pengadilan Negeri atau Pengadilan Agama. Namun pengecualian bagi suami beragama Islam dan dilakukan secara Islam berakibat pada: a) tidak ada saling mewarisi antara suami isteri apabila salah satu pihak meninggal dunia, b) suami berhak untuk berpoligami, c) suami berhak menthalak, d) suami berhak merujuk istrinya (tanpa akad nikah baru). Hal-hal tersebut tetap diperbolehkan walaupun menurut agama pihak wanita tidak memungkinkan terjadi (Aulawi, 1980).

Hubungan hukum orang tua dan anak diharapkan memberi keharmonisan dalam keluarga demi tercapainya tujuan dalam perkawinan, karena anak hadir sebagai fungsi regenerasi, fungsi rekreatif, fungsi protektif dan fungsi ekonomis. Status hukum bagi anak yang lahir dari perkawinan beda agama merupakan anak yang sah, karena perkawinan beda agama yang telah dicatatkan oleh negara dan dilakukan menurut hukum agama serta memenuhi syarat perkawinan. Undang-Undang Perkawinan dalam Pasal 5 ayat (1) menjelaskan mengenai status hukum anak memberikan konsekuensi yuridis terhadap kedua orang tuanya. Kewajiban sebagai orang tua dalam perannya sebagi ibu dan ayah berlaku seimbang dalam mendidik sebaik mungkin, karena kewajiban tersebut akan berlaku sampai anaknya telah kawin atau cakap untuk bertanggung jawab terhadap nasib hidupnya, bahkan kewajiban akan tetap melekat walaupun perkawinan orang tuanya dinyatakan putus.

Implikasi yuridis berdasarkan UUP menyatakan bahwa anak yang lahir dari perkawinan berbeda agama namun masih memiliki ikatan perkawinan yang sah, anak tersebut berhak untuk menentukan pilihan untuk dirinya sendiri, utamanya adalah pilihan terhadap agama yang akan dianut tanpa paksaan dari pihak manapun sekalipun orang tua bahkan negara.

Perihal harta kekayaan yang terbentuk dalam sebuah ikatan perkawinan merupakan hal yang wajar dan pasti akan ada, hukum perkawinan membagi harta dalam dua macam yakni harta bersama dan harta bawaan. Harta bersama merupakan harta kekayaan yang diperoleh baik secara masingmasing ataupun bersama suami isteri selama perkawinan sah berlangsung, sedangkan harta bawaan merupakan harta benda yang telah dimiliki sebelum terjadinya perkawinan sah antara pasangan suami dan isteri tersebut.

Terbentuknya harta bersama berdasarkan waktunya, telah dijelaskan dalam Pasal 35 ayat(1) UUP bahwa sejak terjadi ikatan perkawinan secara sah hingga ikatan perkawinan tersebut telah putus, maka ruang lingkup harta bersama ini terbatas pada hasil dari usaha pasangan suami isteri tersebut, terlepas dari warisan atau hadiah dari keluarga asal. Harta bersama juga memiliki konsekuensi yuridis terhadap tanggung jawab yang juga berlaku secara seimbang, maka suami atau isteri tidak diperkenankan menjual atau memindah tangankan harta bersama tanpa adanya persetujuan pasangannya. Apabila dalam ikatan perkawinan sah terjadi percekcokan berakhir pada perpisaham, maka harta yang tergolong sebagai harta bersama harus dibagi adil, bersama berdasarkan persetujuan bersama. 


\section{SIMPULAN DAN SARAN}

\section{Simpulan}

Dari hasil analisis data, dapat dsimpulkan bahwa perkawinan beda agama dalam Undang-Undang Perkawinan tidak diatur secara tegas dan pasti, maka dapat dikatakan terjadi kekaburan hukum dan ketidakpastian terhadap praktik perkawinan beda agama di Indonesia. Undang-Undang Nomor 1 Tahun 1974 tentang Perkawinan khususnya Pasal 2 ayat(1) lebih merujuk pada sahnya perkawinan berdasar hukum agama dan kepercayaannya, namum dalam realisasinya masih ada pasangan yang tetap ingin melangsungkan perkawinan dengan agama yang berbeda melalui jalur permohonan penetapan pengadilan, penundukan sementara pada salah satu hukum agama dan perkawinan yang dilangsungkan di luar negeri, yang kedua penolakan perkawinan beda agama tergolong diskriminatif karena tidak sesuai prinsip dasar HAM. Terdapat konflik norma antara Pasal 28 UUD 1945 dan Pasal 3 ayat (3) UU HAM dengan Pasal 2 ayat (1) UU Perkawinan yang berakibat pada konsekuensi yang diterima salah satu calon pasangan yakni penundukan diri atas agama yang dianutnya untuk mengikuti agama pasangannya.

\section{Saran}

Adapun yang disarankan oleh peneliti berdasarkan hasil penelitian ini adalah Selaku akademisi Ilmu Hukum didorong untuk memberikan pandangan konkrit terhadap fenomena yang terjadi khususnya mengenai perkawinan beda agama di Indonesia. Adanya kekaburan norma terhadap perkawinan beda agama di Indonesia dan konflik norma yang termuat dalam Undang-Undang Perkawinan dengan Undangn-Undang Hak Asasi Manusia diharapkan mendapatkan penyempurnaan dari Pemerintah untuk segera harmonisasi dari berbagai aturan yang terkait dengan perkawinan.

\section{DAFTAR PUSTAKA}

Ahmad, B. (2008). Metode Penelitian Hukum. Pustakasetia.

Aulawi, W. (1980). Beberapa Aspek dari Perkawinan Antar Agama. Bulan Bintang.

Daeng, Y., \& Ariga, F. (2017). Larangan Pernikahan Beda Agama Ditinjau dari Perspektif Hak Asasi Manusia. Journal Equitable 87, 2(2), 70-87.

Dardiri, A. H., \& Tweedo, M. (2013). Pernikahan Beda Agama Ditinjau Dari Perspektif Islam dan Ham. Khazanah, 6(1), 99-117.

Gautama, S. (1980). Hukum Antar Golongan (suatu pengantar). Ichtiar Baru-Vanhoeve.

HS, S. (2014). Perkembangan Hukum Jaminan di Indonesia. Raja Grafindo Persada.

J, S. (1995). Perikatan yang Lahir dari Perjanjian. Citra Aditya Bakti.

Kambey, E. E. (2017). Analisis tentang Perjanjian Perkawinan Ditinjau dari Putusan Mahkamah Konstitusi Nomor 69/PUU-XIII/2015. Lex Privatum, 5(9), 1-14.

Taufik, M. (2013). Hukum Perlindungan Anak dan Penghapusan Kekerasan. Rineka Cipta.

Usman, S. (1989). Kawin Lari dan Kawin Antar Agama. Liberty.

Yonesta, F., Isnur, M., Hidayat, N., Febrian, S. H., Sihite, I. L., \& Biky, A. (2012). Agama, Negara dan Hak Asasi Manusia. In Journal of Chemical Information and Modeling (Vol. 53, Issue 9). LBH Jakarta. 